\title{
O QUE SIGNIFICA TORNAR-SE OUTRO? Xamanismo e contato interétnico na Amazônia*
}

\section{Aparecida Vilaça}

As relações entre 0 xamanismo e 0 contato com a sociedade nacional são tema constante na literatura etnológica. De um modo geral, o que se enfatiza é uma relação de determinação em sentido único: a inserção no mundo ocidental provocaria ora 0 fim do xamanismo, ora a sua efervescência. É o caso, por exemplo, dos grupos Tupi-Mondé da Amazônia Meridional. De acordo com Brunelli (1996, pp. 256-260), o xamanismo desapareceu em alguns desses grupos logo após o contato, para ser retomado alguns anos depois, como marca de identidade étnica. Entre os Bororo, segundo Crocker (1985, pp. 329-331), o impacto do encontro com a sociedade brasileira foi responsável pelo desaparecimento do "xamanismo vertical". Em contraposição, entre os Yagua, o número de xamãs vem aumentando com o contato (Chaumeil, 1983, p. 261).

* Publicado originalmente, sob o título "D evenir autre: chamanisme et contact interethnique en Amazonie Brésilienne", no Jaumal de la Sociéé des Amúicanistes $\mathrm{n}^{\boldsymbol{\theta}}$ 85, 1999, pp. 239-260. Agradeço a Eduardo Viveiros de Castro e a Peter Gow pela leitura crítica de uma primeira versão deste artigo. A pesquisa de campo entre os Wari' foi financiada pela Wenner-Gren Foundation for Anthropological Research, pela Finep e pela Fundação Ford.
Há também relatos da apropriação dos símbolos cristãos por xamãs nativos, sendo os mais famosos os referentes aos Tupinambá seiscentistas. Do mesmo modo que os missionários usavam algumas premissas do discurso dos xamãs-profetas, prometendo o fim dos males com a conversão, esses xamãs apropriavam-se do discurso dos padres e afirmavam estar em contato direto com Deus (Viveiros de Castro, 1992, pp. 33-34). Essa incorporação de símbolos e práticas cristãs pelos xamãs nativos é freqüente em movimentos messiânicos, como aqueles que ocorreram no alto rio Negro, descritos por Hugh-Jones (1996, pp. 47-49) e Wright (1996, pp. 110-114). É bem documentado também o movimento no sentido inverso, ou seja, da apropriação de práticas xamânicas nativas pela população cabocla (Gow, 1996, pp. 105-111; Taussig, 1993). ${ }^{1}$

0 meu objetivo neste artigo é analisar, com base na etnografia wari', grupo de língua Txapakura da Amazônia Meridional, a relação entre xamanismo e contato interétnico por uma outra perspectiva. Pretendo mostrar que, no lugar de uma determinação direta entre a intensidade da prática xamânica e 0 grau de contato (ora positiva, ora negativa) e de apropriação de práticas 
ocidentais, religiosas ou seculares, pelos xamãs, 0 que chama a atenção entre os Wari' é que 0 processo de contato com os Brancos é pensado pela ótica do xamanismo. Assim como os xamãs, simultaneamente humanos e animais, os Wari' hoje possuem uma dupla identidade: são Brancos e Wari'.

Um desenho realizado em 1987 por Maxün Hat, a quem eu solicitei que representasse um homem wari', é revelador. Nele, a figura de um homem é construída por traços duplos, de modo que a roupa em estilo ocidental, como aquela com a qual os Wari' se vestem hoje, se sobrepõe ao corpo sem, no entanto, escondê-lo. O que se vê, na verdade, são dois corpos simultâneos: 0 do Branco, por cima, e o do Wari', por baixo. Esse desenho nos remete a diversos outros contextos etnográficos, e tomo como exemplo os Kayapó do Brasil Central, tão evidentes na mídia nos últimos anos: as vestimentas ocidentais não cobrem totalmente as pinturas corporais, ou estas são explicitamente exibidas nas partes descobertas dos corpos, convivendo com shorts e calças compridas. 0 ex-deputado federal brasileiro, o xavante Mario Juruna, até hoje 0 único índio a ser eleito para um cargo político importante no Brasil, era conhecido por compatibilizar cocares de penas com ternos e camisas sociais.

Conklin (1997, pp. 716-717) observa que, até os anos 1980, os índios amazônicos costumavam usar roupas ocidentais completas, conseqüência da percepção do impacto negativo de seus corpos nus, lábios e orelhas perfurados, entre os representantes da sociedade nacional, desde a população rural vizinha aos habitantes das grandes cidades. Passar a usar roupas foi um modo não só de serem aceitos, mas de serem deixados em paz, e de continuarem a viver como antes, quando longe dos olhos dos Brancos. Turner (1991, p. 289) faz comentários análogos para os Kayapó, que, em 1962, andavam quase todos vestidos ao modo ocidental, sendo que os homens retiraram os batoques labiais e cortaram os cabelos. Para Conklin (1997, p. 712), as mudancas ocorridas a partir dos anos 1980 tiveram relação com a imposição aos índios de uma visão ocidental específica sobre estética e autenticidade (ver também Weiner, 1997, para uma discussão sobre a relação entre estética e representação). Em suas palavras:

Procuro mostrar que a natureza da eco-política contemporânea - especialmente a dependência em relação à mídia global e organizações nãogovernamentais - intensifica a pressão para que os ativistas indígenas se adequem a determinadas imagens [...] 0 simbolismo visual está no centro dessa história porque a política da aliança indígeno-ambientalista é primariamente uma política de símbolos [...] Símbolos são importantes em todas as políticas, mas eles são centrais no ativismo da Amazônia nativa; sem força eleitoral ou influência econômica, o "capital simbólico" (Bourdieu 1977) da identidade cultural é um dos principais recursos políticos dos índios brasileiros. (Conklin, 1997, p. 712)

Há, entretanto, uma questão que a autora não coloca, e que diz respeito não aos adereços indígenas, mas ao seu complemento: as roupas ocidentais. Se os índios resolveram mudar a sua apresentação, misturando roupas manufaturadas com pinturas e adereços nativos, mesmo que não "tradicionais", por terem tomado consciência de um modelo de indianidade criado no Ocidente moderno, por que não abriram mão por completo das vestimentas ocidentais?

0 caso do ritual dos Nambikwara citado por ela é bastante ilustrativo. Um cineasta havia filmado em vídeo o rito de iniciação feminino, e em seguida exibiu-o aos índios. Estes ficaram insatisfeitos com as imagens, por estarem demasiadamente vestidos. Decidiram reencenar 0 rito para que fosse novamente filmado. Os homens retiraram as camisetas e usaram shorts menores, e as mulheres usaram pedaços de pano enrolados em volta da cintura como saias (Conklin, 1997, p. 719). Sabe-se, pelas belas fotos exibidas por Lévi-Strauss (1955) em Tristes trópicos que os Nambikwara andavam nus. Teriam eles, juntamente com 0 modelo de indianidade, introjetado tão profundamente a nossa noção de pudor que, mesmo sabendo que seriam ainda mais autênticos se completamente nus, não puderam se despir? Talvez, se questionados sobre isso, os Nambikwara ofereces- 
sem uma resposta análoga à dos Wari' quando eu lhes perguntava por que, se as lembranças da vida na floresta, antes do contato, eram tão positivas, não voltavam para lá de vez, abandonando os Brancos e todas as suas coisas. "Porque somos Brancos", diziam eles. O que significa esse "ser Branco" sem abrir mão de ser Wari', e como essa dupla identidade se inscreve no corpo?

Turner (1991) nos oferece um caminho de resposta. A duplicidade visível nos corpos kayapó seria a expressão de um compromisso entre 0 interesse por uma vida integrada ao mundo dos Brancos, com acesso fácil aos cobiçados objetos manufaturados, e a luta pela autonomia. Se, nos anos 1960, os Kayapó procuravam uma espécie de invisibilidade nos contextos de relação com a sociedade nacional, vestindo-se exatamente como Brancos, com calças compridas, camisas, sapatos e óculos escuros, hoje revelam com orgulho a sua identidade indígena. Trata-se, segundo 0 autor, de uma nova forma de consciência, resultante não de transformações cognitivas ao modo estruturalista, mas do processo histórico de confronto interétnico. Em suas palavras: "A casa e o indivíduo tornaram-se, da mesma forma, duplos, diametralmente divididos entre um cerne indígena Kayapó e uma fachada externa composta totalmente ou em parte por bens e formas brasileiras." (Turner, 1991, p. 298).

Se a ambigüidade ou duplicidade do vestuário é certamente uma opção política, refletindo não só uma valorização endógena da tradição, como também a consciência do impacto de símbolos visuais para os Brancos que valorizam índios autênticos, não penso que uma reflexão sobre os processos de confronto esgote as questões suscitadas por tal comportamento. No caso ameríndio, a escolha do corpo como lugar de expressão dessa dupla identidade não é casual. A hipótese que procurarei desenvolver aqui é que, para os Wari' ao menos, a face externa, ocidental, não é uma fachada que cobre um interior mais verdadeiro ou mais autêntico, como sugere Turner (1991, p. 298) para os Kayapó. ${ }^{2}$ Ela é igualmente verdadeira e existe simultaneamente ao corpo wari' nu. ${ }^{3}$ Ao serem Wari' e Brancos simultaneamente, os Wari' vivenciam, como veremos adiante, uma experiên- cia análoga à de seus xamãs, que têm um corpo humano e outro animal. Uma análise do significado do corpo no mundo ameríndio é essencial para compreendermos o papel das roupas ocidentais na constituição desse corpo duplo.

\section{0 corpo ameníndio}

Há 20 anos atrás, em um artigo hoje antológico sobre a noção de pessoa, Seeger, Da Matta e Viveiros de Castro concluíram que o corpo e os processos a ele relacionados são centrais para os ameríndios:

a originalidade das sociedades tribais brasileiras (de modo mais amplo, sul-americanas) reside numa elaboração particularmente rica da noção de pessoa, com referência especial à corporalidade enquanto idioma simbólico focal. $\mathrm{Ou}$, dito de outra forma, sugerimos que a noção de pessoa e uma consideração do lugar do corpo humano na visão que as sociedades indígenas fazem de si mesmas são caminhos básicos para uma compreensão adequada da organização social e cosmologia destas sociedades. (Seeger, Da Matta e Viveiros de Castro, 1979, p. 3)

Como já havia observado Joanna Overing Kaplan (1977, pp. 9-10), a estrutura das sociedades ameríndias não se encontrava onde os etnólogos a procuravam, já que se tomava como referência modelos importados de outras regiões etnográficas, como a Ásia, a África e a Melanésia. Diante da ausência de clãs, linhagens e grupos corporados, postulava-se a fluidez e a falta de princípios integradores nessas sociedades. Examinando algumas etnografias da época, tais como a de Crocker sobre os Bororo, a de Reichel-Dolmatoff sobre os Desana do noroeste amazônico, e a de Overing Kaplan sobre os Piaroa da Venezuela, Seeger, Da Matta e Viveiros de Castro (1979, p. 3) observaram que todas elas davam muito espaço às ideologias nativas sobre a corporalidade: "teorias de concepção, teorias de doenças, papel dos fluidos corporais no simbolismo geral da sociedade, proibições alimentares, ornamentação corporal". Isso não lhes pareceu acidental, ou "fruto de um bas teórico" (idam 
ibidam, mas resultado da centralidade das questões relacionadas à corporalidade na definição da estrutura dessas sociedades. A problemática das qualidades sensíveis evidenciada por Lévi-Strauss, a partir dos mitos americanos, na monumental Mythdogiques (Lévi-Strauss, 1964, 1967, 1968 e 1971) aplicava-se perfeitamente ao nível da organização social (Seeger, Da Matta e Viveiros de Castro, 1979, p. 3).

Recentemente, Viveiros de Castro retomou a questão da corporalidade ameríndia à procura de uma nova síntese, e desenvolveu a sua teoria do perspectivismo ou multinaturalismo. De acordo com esse autor, para diversos povos ameríndios "0 mundo é habitado por diferentes espécies de sujeitos ou pessoas, humanas e não-humanas, que 0 apreendem segundo pontos de vista distintos", relacionados aos seus corpos (Viveiros de Castro, 1996, p. 115). Não se trata daquilo que conhecemos como relativismo multicultural, que supõe

[...] uma diversidade de representações subjetivas e parciais, incidentes sobre uma natureza externa, una e total, indiferente à representação; os ameríndios propõem o oposto: uma unidade representativa ou fenomenológica [...] aplicada indiferentemente sobre uma radical diversidade objetiva. Uma só "cultura", múltiplas "naturezas" [...] Uma perspectiva não é uma representação porque as representações são propriedades do espírito, mas 0 ponto de vista está no corpo. Ser capaz de ocupar o ponto de vista é certamente uma potência da alma [...] mas a diferença entre os pontos de vista [...] não está na alma, pois esta, formalmente idêntica através das espécies, só enxerga a mesma coisa em toda parte - a diferença é dada pela especificidade dos corpos. (Viveiros de Castro, 1996, p. 128)

No lugar de um multiculturalismo teríamos, portanto, um multinaturalismo (idam p. 127).

Se passamos ao caso específico dos Wari', vemos que o corpo (kwee, sempre seguido de sufixo indicador de posse) é o lugar da personalidade, é o que define a pessoa, animal, planta ou coisa. Tudo o que existe tem um corpo, uma substância, que é 0 que lhe dá características próprias. Os Wari' costumam dizer: "Je kwere" ("meu corpo é assim"), que significa: "esse é meu jeito", "eu sou assim mesmo". E também quando se referem a animais ou coisas. Se perguntamos a eles por que os queixadas andam em bando, eles dirão: "Je kweren mjjak" ("o corpo do queixada é assim"); ou por que a água é fria: "Je kwerein kom" ("o corpo da água é assim").

Se tudo tem um corpo, só os humanos - o que inclui os Wari', os inimigos e diversos animais - possuem uma alma, que os Wari' chamam de jam. Enquanto o corpo diferencia as espécies, a alma as assemelha como humanas. Nesse sentido, os Wari' são um caso exemplar do pensamento perspectivista ameríndio. Todos os humanos partilham práticas culturais análogas: vivem em família, caçam, cozinham seus alimentos, ingerem bebidas fermentadas, fazem festas etc. Os diferentes corpos, entretanto, implicam formas diferentes de perceber as mesmas coisas. Assim, tanto os Wari' como 0 jaguar bebem chicha de milho, mas o que 0 jaguar vê como chicha é o sangue, do mesmo modo que 0 barro é chicha para a anta. Tanto 0 jaguar como a anta se concebem como humanos, wari', termo que significa "gente", "nós", e percebem os Wari' como não-humanos, podendo predálos como se fossem caça, ferindo-os com suas flechas.

O caso dos Makuna, grupo de língua Tukano do rio Vaupés, ilustra bem essa questão da humanidade dos animais:

Os peixes são gente [...] As árvores frutíferas que crescem nas margens dos rios são suas roças, as frutas são seus cultígenos [...] Como os homens, os peixes formam comunidades [...] Em suas casas subaquáticas (invisíveis ao olho humano comum) os peixes guardam todos os seus bens, ferramentas e instrumentos como os que as pessoas têm em suas casas [...] Quando os peixes desovam, estão dançando em suas casas subaquáticas [...] Os animais de caça são gente. Eles têm sua própria mente $[\ldots]$ e seus próprios pensamentos $[\ldots]$, como os homens [...] Eles têm malocas e comunidades, têm suas próprias danças e sua própria parafernália ritual e instrumentos [...] É por isso que os animais têm alma; eles têm sua própria 
mente e pensamentos. (Arhem, 1993, pp. 112-113 e 116-117)

A noção do corpo como lugar da diferença não se limita às relações interespecíficas. A sociedade wari' é concebida como sendo constituída por agregados corporais de diversos níveis, sendo suas fronteiras tão variáveis que se torna difícil falar em sociedade (ver Gow, 1991, p. 264, para concepção análoga entre os Piro; Seeger, 1980, pp. 128129, para os Suyá; Da Matta, 1976, pp. 80-81, para os Apinayé). Assim, os parentes próximos podem se afastar e, rompendo o contato, se transformar em inimigos, seres ontologicamente idênticos aos Wari', do mesmo modo que os inimigos podem ser, através do casamento, incorporados como parentes.

É importante ressaltar que o corpo ameríndio não é um dado genético, mas é construído ao longo da vida por meio das relações sociais (Gow, 1991; Da Matta, 1976, p. 88). Entre os Wari', após o nascimento, o corpo da criança, constituído por uma mistura de sêmen e sangue menstrual, vai sendo constantemente fabricado através da alimentação e da troca de fluidos corporais com seus pais, irmãos e parentes próximos. Os filhos adotivos, por exemplo, são considerados consubstanciais de seus pais de adoção e, de maneira análoga, marido e mulher tornam-se consubstanciais com a proximidade física decorrente do casamento (ver O vering Kaplan, 1977, p. 390, para comentário análogo sobre os Canela, apud Crocker). A comida é central na constituição da identidade física tanto dos Wari' como das espécies animais, como veremos no caso dos xamãs.

$\mathrm{Na}$ primeira fase de meu trabalho de campo, ouvia constantemente exclamações do tipo: "Ela não é Wari', não come gongos". Quando finalmente ingeri diante deles algumas dessas larvas, a notícia que se espalhou na aldeia é que eu havia me tornado completamente Wari'. Essa consubstancialidade produzida pelas relações físicas e pela comensalidade (remeto aos Piro analisados por Gow, 1991, pp. 7-8, 114 e 123-124, para a importância da comida na constituição da identidade; e aos Matsinguenga analisados por Baer, 1994, p. 88) é tão efetiva quanto aquela dada pelo nascimento, de modo que aqueles que vivem juntos, comem juntos ou partilham a mesma dieta alimentar vão se tornando consubstanciais, especialmente se passarem a se casar entre si. Mais do que simples substância física, o corpo ameríndio é, como já observou Viveiros de Castro (1996, p. 128), "um conjunto de afecções ou modos de ser que constituem um habitus".

Voltando às observações iniciais sobre 0 desenho wari' e as vestimentas kayapó, devemos ressaltar que o corpo não é meramente lugar de expressão da identidade social, mas 0 substrato onde ela é fabricada, de modo que os adereços e roupas constituem menos uma "pele social" que socializaria externamente um substrato natural interno, como propõe Turner (1971, p. 104) para os Kayapó, do que o motor de um processo corporal. A minha hipótese é que não há uma diferença substantiva entre as roupas animais usadas pelos xamãs e pelos próprios animais (quando se mostram aos índios), os adereços corporais propriamente indígenas, e as roupas manufaturadas trajadas por índios em contato com Brancos. São todos igualmente recursos de diferenciação e de transformação do corpo, que não podem ser isolados de recursos análogos tais como as práticas alimentares e a troca de substâncias através da proximidade física. Em um certo sentido poderíamos mesmo dizer que as roupas ocidentais usadas pelos índios seriam mais tradicionais ou autênticas do que os enfeites plumários a elas justapostos, já que a roupa seria o modo indígena de ser Branco, um devir previsto por seu sistema conceitual. Os enfeites plumários, por sua vez, seriam o modo Branco de ser índio.

Viveiros de Castro, nesse mesmo artigo sobre 0 perspectivismo, chamou a atenção para 0 fato de as roupas, máscaras e adereços serem instrumentos e não fantasias. Comentando a parafernália ritual, ele observa: "Estamos diante de sociedades que inscrevem na pele significados eficazes, e que utilizam máscaras animais [...] dotadas de poder de transformar metafisicamente a identidade de seus portadores, quando usadas em contexto ritual apropriado." (Viveiros de Castro, 1996, p. 133). Dentre os diversos exemplos temos os Yagua da Venezuela, cujos xamãs utilizam "vestimentas má- 
gicas" que os possibilitam ver sob a água (Chaumeil, 1983, p. 51); os Kogi da Colômbia, para os quais um personagem mítico transforma-se em jaguar ao ingerir substância alucinógena (na forma de uma bola azul que ele coloca na boca) e vestir uma máscara de jaguar, passando a "perceber as coisas de um modo diferente, o modo como 0 jaguar as vê" (Reichel-D olmatoff, 1975, pp. 55 e 58); os Baniwa do noroeste amazônico, que expressam a transformação do pajé em jaguar como "vestir a camisa do jaguar" (Wright, 1996, p. 79); e os Desana, entre os quais o uso de peles, máscaras e outros "disfarces" é o que caracteriza os animais como tais, possibilitando também a transformação dos xamãs em animais (Reichel-Dolmatoff, 1975, pp. 99, 115, 120, 124 e 125). Nesse sentido, e contrariamente ao que diz Turner (1971, p. 104), as roupas, pinturas e máscaras seriam antes um meio de naturalizar substratos culturais indiferenciados (ver Viveiros de Castro, 1996, p. 130) do que de culturalizar um corpo excessivamente natural. A diferenciação é dada pela naturalização e não pela culturalização, visto que a cultura é comum aos diversos seres, sendo justamente 0 que os identifica como humanos. A "permutabilidade objetiva dos corpos está fundada na equivalência subjetiva dos espíritos" (idkm 133). Os Makuna oferecem um ótimo exemplo dessa permutabilidade dos corpos:

Apesar de os peixes viverem no mundo do rio, facilmente se transformam em pássaros, micos, roedores, porcos-do-mato, e outros animais de caça que comem frutas. Quando a comida do rio está escassa, os peixes se convertem em pássaros e animais terrestres para procurar comida na floresta. (Arhem, 1993, p. 115)

Retomo aqui a anedota antilhana citada por Lévi-Strauss (1952) em Raça e históia e retomada por Viveiros de Castro (1996, p. 123) para ilustrar 0 perspectivismo: enquanto os espanhóis investigavam se os índios tinham ou não alma, estes se dedicavam a afogar os Brancos para observar se seus cadáveres eram sujeitos à putrefação. Entenda-se: os índios queriam saber que tipo de humanos seriam esses Brancos, e isso só lhes parecia possível mediante 0 estudo das peculiaridades de seus corpos.

Ora, é possível estabecermos uma relação de continuidade entre este episódio ocorrido há 500 anos e alguns eventos recentes do cenário ecoindigenista brasileiro reportados por Conklin (1997, p. 727), e que remetem diretamente à questão da apresentação corporal que vimos analisando aqui. Em 1984, os índios Pataxó, habitantes da costa da Bahia, ameaçados por fazendeiros que reinvidicavam suas terras, alegando não serem eles índios autênticos, foram visitados por uma comitiva chefiada pelo xavante Mário Juruna, então deputado federal, que propôs a eles que abandonassem as terras. Juruna retornou à cidade, após ter sido expulso pelos Pataxó, afirmando que a reserva era "ocupada por uma maioria de caboclos e apenas meia dúzia de índios" (CEDI, 1984, p. 293). A matéria publicada na Fdha da Tarde (4/9/1984) sobre 0 episódio, que escandalizou os defensores dos direitos indígenas, termina da seguinte forma: "Indagado sobre os indícios que o levaram a pôr em dúvida a autenticidade dos índios da reserva, [Juruna] respondeu: 'Índio não tem barba, nem bigode, nem cabelo no peito'." (cf. CEDI, 1984, p. 293; ver também Conklin, 1997, p. 727).

Mais recentemente, em 1992, durante um encontro ecológico internacional no Rio de Janeiro, o Earth Summit, os povos nativos organizaram eventos paralelos, parte deles no interior de uma reprodução de aldeia indígena, especialmente construída para este fim. Os Kayapó, tomando para si o papel de anfitriões, passaram a atuar como porteiros, decidindo quem poderia ou não entrar nas casas: além de jornalistas e organizadores credenciados, somente foram admitidos indivíduos usando roupas exóticas e adereços indígenas. De acordo com 0 antropólogo que relatou 0 episódio para Conklin, dois índios norte-americanos foram barrados quando trajando roupas comuns, sendo admitidos ao retornarem no dia seguinte com enfeites plumários.

Conklin (1997, p. 727) interpreta esses episódios como resultantes da imposição sobre os índios de um modelo de indianidade construído pelo Ocidente e focalizado na estética corporal. Quero aqui chamar a atenção justamente para a "autenti- 
cidade" desse modelo, e sugerir que é precisamente por isso que foi tão prontamente aceito e incorporado pelos índios. Trata-se, como propus a respeito da relação entre os Wari' e o cristianismo da Missão Novas Tribos do Brasil (Vilaça, 1996a, 1996b e 1997), de um encontro de ideologias. É preciso, portanto, relativizar a observação de Turner (1991) sobre a impossibilidade de se compreender essa adoção de um duplo vestuário como uma transformação cognitiva ao modo estruturalista. Se estas transformações são fruto de uma conscientização política, só foram possíveis ou aconteceram dessa forma porque são compatíveis com aspectos estruturantes do pensamento, tais como a lógica dualista, que, segundo Lévi-Strauss (1991) teria relação com a abertura estrutural dos ameríndios ao Outro, e a noção de corporalidade como central na constituição da pessoa. Em relação ao primeiro ponto - a abertura ao Outro - , devemos observar que a noção exclusivista de tradição parece ser estranha a diversas culturas não ocidentais, como fica evidente nessas misturas de vestimentas que expressam misturas de identidades. Voltaremos a isso.

Passemos agora aos xamãs, para quem a possibilidade de transformação de corpos constitui a essência da sua atividade. No caso wari', a aproximação entre as transmutações xamânicas, que fazem a conexão entre 0 mundo dos Wari' e 0 dos animais, e aquelas relativas ao contato interétnico tem como fundamento primeiro a equivalência entre animais (karawa) e inimigos (njjam), categoria na qual os Wari' classificam os Brancos. Tanto os inimigos como os animais mantêm com os Wari' uma relação que se caracteriza pela guerra e pela predação. Por meio dessas atividades produz-se uma ruptura no continuum de humanidade, sendo os predadores definidos como humanos, wan', e as presas como não-humanas, karava, posições estas essencialmente reversíveis.

\section{Os xamãs}

O xamã wari' (ko tuku ninim) é "aquele que vê", um ser especial, parte humano, parte animal. Tudo começa com uma doença grave, em que um animal agride o espírito do futuro xamã, interessa- do em torná-lo seu companheiro, membro da sua espécie. 0 espírito do doente chega à casa dos animais daquela espécie determinada, e já pode vê-los como humanos, ou seja, adota o ponto de vista do animal. É banhado com água morna e, ao modo dos sogros wari', eles lhe oferecem uma menina, que será sua esposa no futuro, quando, ao morrer, virar definitivamente animal. ${ }^{4}$ Quando um xamã está velho, costuma-se dizer que a sua esposa animal já virou moça, e que ele irá em breve juntar-se a ela, consumando o casamento e a transformação em animal. Como no contexto da relação entre agregados corporais no interior da sociedade, o casamento é também aqui essencial na completude da mudança.

0 futuro xamã recebe ainda 0 urucum e 0 óleo de babaçu mágicos, revestimentos corporais por excelência, que vão caracterizá-lo como membro da espécie agressora, dotando-o do ponto de vista do animal e de poder de cura. A partir de então esse homem (são raros os registros de mulheres xamãs) tem um espírito atuante, presente todo o tempo como um duplo animal, que vive junto aos seus iguais. Sobre o espírito dos xamãs, os Wari' dizem, dependendo do animal que ele "acompanha" (necessariamente um animal de uma espécie com espírito): "Ele é queixada completamente" (Mijak pin na), "Ele foi para os queixadas" (Mao ma jam mjak), ou "Ele está com as antas" (Peho non min). Repito aqui as palavras de Orowam, xamã wari':

Eu sou jaguar. Sou um jaguar de verdade. Eu como animais. Quando tem gente doente, eu vou ver e ele fica bom. Ela tem coisas em seu coração, a pessoa doente. Ele esfria (fica bom, sem febre). Eu tenho óleo de babaçu e urucum. Eu vou ao mato. Vou longe, ver outras pessoas. Vejo Brancos, vejo todo mundo. Eu sou um jaguar verdadeiro, não sou um jaguar de mentira. (Orowam em 1995)

$\mathrm{Ou}$, como afirmou o mesmo xamã alguns anos antes, em 1987: “O jaguar é meu parente verdadeiro. Meu corpo verdadeiro é jaguar. Há pêlos em meu corpo verdadeiro". A identidade é explicitamente concebida como situada no corpo e relacionada ao parentesco. 
Assim como na constituição das relações de consubstancialidade, a comensalidade é fundamental na definição do xamã como membro de determinada espécie, de modo que um xamã pode "trocar" de espécie se passar a acompanhar outros animais, o que significa que, além de andar ao lado desses animais, vai comer como eles e junto com eles. Os xamãs wari' costumam dizer que visualmente não há qualquer diferença entre as espécies animais dotadas de espírito, visto que percebem, todas, com a forma humana: o que as diferencia mesmo são seus hábitos. A freqüente incapacidade de diferenciar visualmente as espécies animais, de percebê-las na forma animal, torna o xamã um mau caçador. Maxün Hat, para o desespero de sua esposa, não consegue atirar nos animais que encontra porque os vê como humanos. Partilhar a mesma identidade torna a predação e a devoração infactíveis (Vilaça, 1998), não por causa de prováveis doenças advindas do consumo de um consubstancial, mas devido à percepção da identidade (remeto a Vilaça, 1992, para a descrição de algumas experiências de iniciação xamânica).

O xamã caracteriza-se por possuir dois corpos simultâneos: um corpo humano visível pelos Wari', que se relaciona com eles normalmente, como membro de sua sociedade, e um corpo animal que ele percebe como humano, e que se relaciona com os demais animais daquela espécie também como membro da sua sociedade, que é como a sociedade wari'. Como disse Maxün Hat, só o corpo dele está na aldeia; o seu espírito está com os queixadas, dia e noite. $\mathrm{O}$ que acontece algumas vezes é uma espécie de curto-circuito: de acordo com sua esposa, ele não dorme bem de noite, batendo os dentes como se estivesse comendo frutos. 0 mesmo acontece com 0 xamã-jaguar Orowam, que assusta os seus vizinhos rugindo enquanto dorme.

A presença do xamã no seio do grupo tem duas faces. A primeira é positiva, atuando na profilaxia e na cura de doenças. Como homens em expedição guerreira, os espíritos animais podem chegar até os Wari' em grupo, trazidos pelo vento, gritando: "Vamos flechar inimigo!". Dentre esses animais podem estar também alguns xamãs, geralmente estrangeiros, membros de outros subgrupos wari'. ${ }^{5}$ Os xamãs locais conseguem vêlos e tentam logo estabelecer um diálogo, evitando que os Wari' tenham seus espíritos atingidos por essas flechas e caiam doentes. Começam por forçar-lhes uma adequação da visão: "Vejam bem, não são animais, são uan'! São seus parentes!”. Os animais então reconhecem os Wari' como iguais e se retiram. Caso alguém adoeça, o xamã atua evitando que a vítima se transforme em animal, retirando de seu corpo todos os traços deixados pelo animal agressor, e tentando resgatar, junto aos animais, o espírito que já está em vias de se transformar em animal. Essa transformação pode ser completa e conduzir à morte do corpo, ou a vítima não curada pode continuar viva, quando se torna xamã. No caso de morte, o espírito agredido vai fazer parte da espécie agressora, passando a estar associado a um novo corpo. É interessante acrescentar aqui que, nas mortes causadas por inimigos em guerra, 0 espírito do Wari' morto torna-se membro do grupo inimigo, ganhando um corpo de inimigo, tornando-se irreconhecível aos parentes que porventura se defrontem com ele.

A face negativa da atuação do xamã diz respeito à sua capacidade de se tornar inimigo a qualquer momento, atacando os seus concidadãos, podendo causar mortes. Ele age assim de maneira não intencional, quase que por "falha técnica" (expressão minha): sua visão torna-se deficiente e ele passa a ver os seus parentes como inimigos ou presas animais. Tudo se passa como se os seus diferentes corpos se confundissem, de modo que ele, como Wari', adotasse o ponto de vista do animal. E não só xamãs estrangeiros, provenientes de outros subgrupos wari'; os xamãs locais, classificados por termos de parentesco, como é o costume entre conterrâneos, também estão sujeitos a esses surtos, que lembram os dos matadores de alguns grupos Tupi no período de reclusão (Viveiros de Castro, 1995). Pude certa vez observar o xamã Orowam, cujo espírito é jaguar, preparar-se para atacar as pessoas que 0 circundavam, dentre elas eu e o seu neto classificatório. Ele coçava os olhos e rugia. Seu neto, que percebeu 0 que acontecia, conversou com ele, lembrando-lhe que eram parentes os que estavam ali (incluindome, por gentileza, nesse grupo). 
A impressão final é a de um jogo de espelhos, em que as imagens são refletidas ao infinito: 0 xamã se torna animal, e é como animal que adota a perspectiva dos seres humanos, vari', passando a ver os Wari' como karava, não-humanos. Nesse sentido, o xamã propicia aos Wari', à sociedade como um todo, a experiência, indireta, de um outro ponto de vista, o ponto de vista do inimigo: de uari' passam a se ver como presas, karava, porque sabem que é assim que 0 xamã os está vendo naquele momento. 0 que ocorre é uma dupla inversão: um homem destaca-se do grupo tornando-se animal e adotando um ponto de vista humano (mai') para que o resto do grupo, permanecendo humano (Wari'), possa adotar o ponto de vista animal.

Se os animais são potencialmente humanos, os Wari' são potencialmente presas, de modo que a humanidade não é algo inerente, mas uma posição pela qual se deve lutar todo o tempo. Tudo se passa como se essa lógica sofisticada de predação em mão-dupla tivesse como finalidade principal uma reflexão profunda sobre a humanidade. Os Wari' experimentam uma situação constantemente instável, arriscando-se a viver sempre na fronteira entre o humano e 0 não-humano, como se de outro modo, se não soubessem o que é ser karawa, não pudessem experimentar 0 que é realmente ser humano.

\section{Por uma fisiologia do contato interétnico}

A concepção do xamã como sendo "aquele que vê" a partir de perspectivas diversas, relacionadas à duplicidade de seu corpo, nos remete de volta às observações iniciais sobre o desenho wari', que retrata justamente um homem com dois corpos, embora um deles não seja um corpo animal, mas um corpo de Branco.

0 que chama a atenção na representação wari' do Branco é que ele foi, desde o início, classificado como inimigo, vijam categoria em que os Wari' situavam os outros índios com quem faziam guerra. No início, dizem os Wari', os Brancos eram inimigos pacíficos, e acabaram por se tornar belicosos devido aos ataques constantes que os Wari' lhes faziam. Historicamente, o primeiro período corresponde aos encontros fortuitos entre os Wari' e alguns regionais, no início de nosso século. O segundo momento está relacionado às perseguições que os Wari' sofreram por parte de seringueiros e outros exploradores, desde a década de 1930 até o final dos anos 1950, quando ocorreu a pacificação.

Alguns anos depois da pacificação, os Wari' já não circulavam mais pelas áreas nominadas de seu território. Construíram suas casas nas proximidades de postos indígenas, situados em locais que os Brancos consideravam como sendo de acesso mais fácil, nas imediações do território que costumavam ocupar. Nessas novas aldeias, tornaram-se conterrâneos não só dos Brancos e dos índios de outras etnias, como também dos Wari' de outros subgrupos, os estrangeiros, que antes ocupavam outras áreas nominadas, outros territórios. No entanto, os Brancos são, ainda hoje, chamados újam

Retomando a questão do convívio com pessoas estranhas, em relação aos índios de outras etnias os Wari' vêm realizando um processo de incorporação, procurando torná-los afins e consagüíneos. Constituindo sempre uma minoria em cada aldeia, esses índios casam-se com os Wari', comem a sua comida e falam a sua língua. Se antes eram chamados rijam inimigos, os índios são hoje, em vários contextos, classificados como wari', especialmente quando se quer diferenciálos dos Brancos. Em que pese a atuação do órgão governamental de proteção ao índio, a Funai (Fundação Nacional do Indio), e dos missionários do Conselho Indigenista Missionário (Cimi) no sentido da construção de uma identidade pan-indígena, em que todos os índios seriam igualmente Wari' em contraposição aos Brancos, a incorporação de inimigos, por meio de casamentos, da proximidade física e da partilha de alimentos, é inerente à cultura wari'. Wan' e wijam são antes de tudo posições ocupadas por seres que não são ontologicamente distintos. Essa ontologia única tem como conseqüência lógica a concepção de que todo inimigo é originariamente um Wari' que sofreu um processo de "inimização", determinado por um deslocamento espacial e a ruptura das 
trocas de festas e de mulheres. Desta perspectiva, esse processo de "inimização" é reversível, bastando que haja uma reaproximação geográfica e 0 restabelecimento de casamentos.

Há um bom exemplo desse processo de incorporação de inimigos. Os OroWin - grupo Txapakura de inimigos tradicionais - que sobreviveram ao contato foram sediados pela Funai no posto Negro-O caia, antes habitado exclusivamente pelos Wari'. D epois de algum tempo começaram a ocorrer casamentos mistos, que produziram crianças por meio das quais os Wari' puderam estabelecer laços de parentesco com os OroWin. Uma mulher wari' contou-me que, por ocasião da morte de um homem OroWin, os Wari', um pouco constrangidos no início, sentiram-se impelidos a chorar no funeral, usando tecnônimos para se referirem ao morto, tratando-o assim como um consangüíneo (que é o modo de se tratar um morto do grupo no canto fúnebre). Os OroWin estavam em processo de incorporação ou de "warinização" quando a Funai os transferiu para um outro posto, longe do Negro-O caia. A distância geográfica certamente vai diminuir o volume das trocas matrimoniais, mas os OroWin partiram levando filhos, filhas e netos dos Wari', o que estimula o contato entre eles.

Nos dias de hoje, os Brancos são os únicos a serem chamados insistentemente de rijam inimigo, de modo que hoje wïam é sinônimo de homem branco. Quando os Wari' dizem que os uj̄am estão chegando, não estão prevendo uma guerra, mas apenas a chegada de alguns Brancos para visitá-los ou venderem seus produtos. São inimigos aos quais falta a relação de guerra, o que possibilita a formulação de frases outrora impensáveis, como "eu vou na casa do wjjam pedir anzóis". Tornaram-se conterrâneos, mas não afins e consubstanciais como os demais inimigos.

Vimos que, para os Wari', a identidade entre duas pessoas ou dois grupos é concebida como uma relação de consubstancialidade, determinada pela proximidade física, que tem como consequiência direta a troca de substâncias corporais e a comensalidade. 0 casamento é tão marcado como parte essencial do processo de transformação que, como já mencionei, os Wari' dizem que 0 xamã só vira completamente animal, tornando-se membro efetivo da espécie que 0 seu espírito costumava acompanhar, quando se casa com a sua noivaanimal, que lhe foi prometida no momento da iniciação. É quando o xamã morre e deixa de ser Wari'. Quando Wan e', xamã queixada, estava velhinho, os Wari' costumavam dizer que seus afins-animais o estavam chamando, porque havia chegado a hora dele efetivar a aliança. Quando cheguei ao Negro-O caia, já ciente da morte de Wan $\mathrm{e}^{\prime}$, que eu chamava de pai, as pessoas tentavam amenizar a minha tristeza dizendo que ele estava bem, que havia sido visto por um outro xamã já em sua nova casa, que tinha constituído uma nova família com a esposa animal. A mudança de identidade caracteriza-se antes de tudo como uma mudança de natureza.

A ampla difusão ameríndia da noção de relação e de transformação como troca de substâncias foi afirmada por Seeger, Da Matta e Viveiros de Castro (1979, p. 14):

A visão da estrutura social que a Antropologia tradicional nos legou é a de um sistema de relação entre grupos. Esta visão é inadequada para a América do Sul. As sociedades indígenas deste continente estruturaram-se em termos de categorias lógicas que definem relações e posições sociais a partir de um idioma de substância.

É paradoxal, portanto, que os chamados estudos do contato interétnico relativos aos grupos ameríndios focalizem, de um modo geral, a atenção na relação entre entidades socioculturais (grupos, instituições, indivíduos como "atores sociais" ou "sujeitos históricos") e não entre agregados corporais. Dos estudos pioneiros na linha dos aculturation studies da escola culturalista americana $a^{6}$ até aqueles inspirados na noção de situação colonial de Balandier (1951 e 1971), ${ }^{7}$ passando pelos trabalhos de Darcy Ribeiro (1957 e 1996 [1970]), o que se enfatiza é o encontro entre entidades definidas a prioi nos termos da ontologia ocidental, com forte ênfase nos aspectos "representacionais" da ação e da sociedade. Sendo assim, traços culturais passam de uma sociedade à outra, como nos "estudos de aculturação", ou instituições e atores concretos (mas concebidos em 
termos de "papéis sociais") atuam como mediadores de complexas relações de confronto entre grupos humanos que se concebem como culturalmente distintos (sem que lhes ocorra indagar o que significa esse "culturalmente"), como nos estudos de fricção interétnica iniciados por Cardoso de Oliveira em 1962 e continuados, após reelaborações sucessivas, por seus alunos (ver Oliveira Filho, 1988, pp. 54-59). Mais do que um descaso pelas ricas etnografias dos grupos ameríndios disponíveis a partir dos anos 1960, há um descaso pelo que pensam os índios. ${ }^{8}$ De que modo eles concebem a distinção entre os grupos? Como eles entendem o modo como esse contato acontece? O que essas etnografias nos mostram é que a sociologia indígena é antes de tudo uma "fisiologia", de modo que, no lugar de "aculturação" ou "friç̧ão", 0 que se tem é transubstanciação, metamorfose.

Como caso exemplar do contato entre índios e Brancos pensado como troca de substâncias corporais, cito os Piro peruanos estudados por Peter Gow (1991), que se concebem hoje como "gente de sangue misturado". Como exemplo de contraste entre aculturação e transubstanciação, retomemos o caso dos Pataxó citado acima. Galvão, em um artigo sobre áreas culturais do Brasil realizado nos anos 1950, ao afirmar que os índios do Nordeste, dentre os quais estão os Pataxó da Bahia, seriam "mesclados", aponta a "perda de elementos culturais tradicionais, inclusive a língua" (Galvão, 1979, p. 225). Para o índio xavante Mario Juruna, como vimos, a evidência da não-indianidade dos Pataxó situava-se em outro lugar: em seus corpos.

A "abertura ao Outro", que, segundo LéviStrauss (1991, p. 16), define o pensamento ameríndio, é aqui uma abertura "fisiológica". É curioso que, embora a concepção nativa de sociedade não seja orgânica no sentido que o funcionalismo dá a essa palavra, existe uma relação entre corpo e sociedade que, no afã de "desorganicizar" a sociedade, os modernos estudos processualistas do contato têm deixado de perceber (ver Oliveira Filho, 1988, pp. 35 e 54). Se a sociedade não é um organismo, no sentido de um conjunto de partes funcionalmente diferenciadas, ela é um ente somático, um corpo coletivo formado de corpos, e não de mentes. As fronteiras, que se situam em diversos níveis, separando os parentes dos não-parentes, e estes dos inimigos, são fronteiras corporais, e o que o grupo consubstancial, uma espécie de coletivo "biológico", troca com outras unidades, igualmente concebidas, são substâncias: alimentos, sêmen, suor, sangue e carne humana (ver Gow, 1991, p. 261, para os Piro; Seeger, 1980, pp. 127-31, para a diferenciação entre corporação e corporalidade).

A partir daí é interessante pensar o significado, para os ameríndios, daquilo que costumamos chamar de tradição. Em um artigo sobre o conceito de tradição entre os Akha (Birmânia/ Mianmar), Tooker (1992) observa que para eles o termo zán, que significa "modo de vida", "modo de fazer as coisas", "costumes", "tradição", caracteriza-se como um conjunto de práticas, e é concebido como uma carga que se leva em um cesto. O idioma da tradição é, portanto, "exteriorizante", e se opõe à nossa idéia de tradição como um conjunto de valores internalizados, aos quais se adere, como disse Viveiros de Castro (1992, p. 25), como a um sistema de crenças, e que tem relação com uma concepção "teológica" da cultura que nos é própria.

Tooker começa 0 artigo relatando 0 caso de uma família chinesa que decidiu tornar-se Akha: "Eles se mudaram para uma aldeia Akha, construíram uma casa no estilo Akha, com um altar ancestral Akha, adotaram uma genealogia Akha, passaram a falar a língua Akha, a vestir raupas Akha e tornaram-se Akha." (Tooker, 1992, p. 800; grifo meu). Se quisessem se tornar novamente chineses, bastaria fazerem 0 caminho inverso, como fez um casal que, após passar uns dias na cidade e se tornar cristão, voltou à aldeia, "reconvertendo-se" aos costumes Akha (idm p. 799).

Eu diria que, para os ameríndios, o idioma da tradição também é exteriorizante, mas não se trata aqui de uma carga, como um conjunto de práticas que se carrega, porque, como vimos, os seres humanos têm, todos, as mesmas práticas: bebem cerveja de mandioca ou milho, vivem em família, fazem guerra. A diferença entre eles é dada pelo ponto de vista, que é determinado pela constituição física. Desse modo, tradição é corpo, substância. Poderíamos mesmo dizer que, em um certo sentido, a tradição é internalizada, mas não como 
crença, como um atributo do espírito, e sim como comida, como líquidos corporais e roupas, substâncias que constituem o corpo. Se para os Akha mudar de tradição é trocar de carga, para os ameríndios é trocar de corpo.

Em um artigo sobre as transformações da noção de cultura no noroeste amazônico (Tukano), Jackson (1995, p. 18) desvencilha-se de uma noção "biológica" de cultura, que, em suas palavras, associaria ter uma cultura ao modo como os animais teriam pêlos e garras, a favor de uma noção mais dinâmica, na qual a cultura seria como 0 repertório de um músico de jazz, ou seja, como algo que acontece como um improviso. Mesmo se considerarmos a propriedade da observação, que teve como intenção criticar, ao modo de Conklin (1997), a imposição aos índios de uma noção de autenticidade que lhes é estranha, chama a atenção que algo essencial lhe tenha escapado no exemplo que escolheu para representar o modelo ao qual viria se contrapor, do mesmo modo que a relação entre corpo e sociedade escapou aos críticos do modelo "naturalizado" de sociedade, como observei antes. A concepção de pêlo animal, se considerada do ponto de vista dos índios, é ela mesmo essencialmente dinâmica, e distante de uma concepção genética, sendo pouco apropriada como metáfora para fixidez. Como Arhem mostrou para um grupo também Tukano, e como vimos analisando aqui, sabe-se que os animais podem trocar de pêlo, transformando-se assim em seres de outras espécies. Se a "cultura" torna-se "natureza", ela torna-se intrinsecamente mutante, como querem os processualistas. Não basta, portanto, adicionar uma dimensão histórica à velha noção de cultura, sendo necessário um deslocamento radical de perspectiva, só possível se adotamos a perspectiva dos índios.

Retomando o caso dos índios americanos barrados pelos Kayapó na entrada da reunião do Earth Summit, é compreensível que aqueles que foram considerados índios um dia depois pelos porteiros kayapó não o tivessem sido um dia antes. Não foi um equívoco, como parece aos nossos olhos, resultante de um processo de opressão ideológica: é provável que, aos olhos dos Kayapó, no dia anterior, quando usavam trajes ocidentais completos, eles não fossem índios, apesar de 0 serem no dia seguinte. Tal tipo de afirmação teria, para os Kayapó, um significado absolutamente diferente daquele que lhe atribuiríamos, e que poderia ser aproximado do caso dos chineses tornados Akha descrito por Tooker. A seguinte afirmação do líder indígena Marcos Terena (1981), ativista do movimento pró-índio no Brasil, vai ao encontro desta idéia: "A sociedade envolvente, seus costumes, seriam apenas uma capa. Por uma questão de sobrevivência, o índio usaria essa capa, assim como você usa uma capa para se proteger da chuva [...]". Assim como a observação de Chaumeil (1983, p. 157, nota 11) referente à resistência à adoção de vestimentas ocidentais pelos Yagua: "[...] porque adotar as roupas dos Brancos é também, de uma certa maneira, tomar-se Branco".

É importante marcar que, embora possa funcionar como um equipamento, a roupa não pode ser dissociada de todo um contexto de transformação. Assim, quando os Wari' dizem que estão virando Brancos, explicam que hoje comem arroz e macarrão, usam shorts e se lavam com sabão, do mesmo modo que um xamã-jaguar se sabe jaguar quando tem pêlos em seu corpo, come animais crus e anda em companhia de outros jaguares. A roupa é parte constitutiva de um conjunto de hábitos que formam o corpo.

Uma observação de Carneiro da Cunha (1998, p. 12) sobre a importância das viagens para a formação do xamã no ocidente amazônico é interessante para ilustrarmos 0 argumento. De acordo com a autora, nos dias de hoje as viagens ao modo ocidental, que se caracterizam por deslocamentos espaciais e implicam estadias em diferentes cidades, são tidas como equivalentes às viagens da alma, substituindo com vantagens a aprendizagem tradicional em alguns contextos, como entre certos grupos Pano. Carneiro da Cunha cita como exemplo o caso de Crispim, um Jaminaua considerado, durante décadas, o mais reputado xamã do alto Juruá e que esteve no Ceará e em Belém, onde teria estudado. Considera que o significado maior dessas viagens estaria em propiciar aos xamãs a oportunidade de aprender sobre o mundo dos Brancos. Ao unir o global (o ponto de vista das cidades e dos Brancos) com 0 local, Crispim 
tornou-se um tradutor, mediador da relação entre mundos diferentes, atributo constitutivo central da atividade xamânica. Mas em que consistiriam exatamente essas viagens, e de que forma se dá o "aprendizado" sobre o mundo dos Brancos? A descrição da autora nos dá uma pista:" "De sua vida, conta-se que foi criado por um padrinho branco que o teria levado para o Ceará e, após um assassinato em que teria sujado as mãos, para Belém, onde teria estudado, ele teria voltado para o Juruá" (Carneiro da Cunha, 1998, p. 12).

0 que essa descrição sugere é que as viagens, longe de constituírem percursos essencialmente visuais, como para nós (visitas a museus e outros lugares típicos), envolvem, antes de tudo, 0 estabelecimento de relações sociais intensas, a convivência (pacífica ou não) com pessoas desses outros mundos. É exatamente 0 que dizem alguns Wari' ao descreverem as suas viagens por cidades: falam da comida que partilharam com esses Brancos, das agressões físicas e do estreito convívio nas mesmas habitações. Conclui-se, assim, que 0 aprendizado aqui vem da experiência ligada ao corpo, e arrisco-me a dizer que é justamente por constituírem "percursos corporais" que essas viagens às cidades são equivalentes às viagens xamânicas para os Pano.

Retomemos a questão da tradição. Ao dizerem que são "Brancos completamente", os Wari' não entendem que estão perdendo a sua tradição, ou a sua cultura, como poderíamos pensar ao vêlos beber chicha de macaxeira ou álcool, comer farinha, usar a espingarda, dançar forró. Acontece que têm agora a experiência de um outro ponto de vista. Como o xamã-onça pode ver o sangue como chicha, os Wari' sabem que a farinha de macaxeira é a pamonha dos Brancos, ou que o forró é o seu tamara.

Como me ensinou Paletó no Rio de Janeiro, é preciso saber o que é a chicha dos Brancos, o que é a guerra para eles, ou o mundo subaquático dos mortos. Se dentro da perspectiva relativista 0 idioma da tradução é o da cultura, no "multinaturalismo" (Viveiros de Castro, 1996) wari' o idioma é 0 da natureza. Nos primeiros dias de Paletó no Rio, um amigo nos convidou para a sua festa de aniversário. Logo que chegamos, ofereceu-nos bebidas, e Paletó aceitou um copo de Coca-Cola. Verteu-o de uma só vez, e nosso anfitrião, entendendo que ele estava com sede ou que havia apreciado muito o refrigerante, imediatamente ofereceu-lhe outro copo cheio, que ele bebeu de um só gole. Somente depois do terceiro ou quarto copo, quando Paletó começou a arrotar, é que entendi que ele estava tomando a Coca-Cola por chicha. Como essas coincidências que ocorreram no Havaí, e que cada vez mais confirmavam a identidade entre Cook e Lono (Sahlins, 1981, 1985 e 1995), o meu amigo portou-se como um típico anfitrião de uma festa wari': oferecia cada vez mais bebida ao seu convidado. Paletó, na posição de convidado, não só devia verter os copos de uma só vez, como não podia recusar cada novo copo que lhe era oferecido. Foi o que fez, e continuaria fazendo até vomitar (para aguentar mais), se eu não interferisse, perguntando: "Você quer parar de beber?" Ele respondeu: "E pode?" A festa de chicha dos Brancos é com Coca-Cola, mas o importante é que não pode ser outra coisa que uma festa de chicha.

Reichel-D olmatoff (1975, p. 74) observa 0 que parece ser uma incoerência no discurso dos Desana, grupo Tukano do Vaupés colombiano. Segundo ele, quando perguntados sobre a existência de espíritos animais, os índios algumas vezes respondem que eles não existem mais, que eram crença dos antepassados. Tudo teria sido esquecido desde a chegada dos missionários. No entanto, essas mesmas pessoas, no dia seguinte, agem como se os espíritos fossem uma realidade incontestável: contam relatos de encontros na floresta, preparam poções mágicas etc. Não se trata de aculturação, afirma o autor, nem tampouco de uma interpretação realista do mundo. O que acontece é que os espíritos fariam parte de uma outra dimensão, tão real quanto aquela da vida diária, mas que normalmente só pode ser acessada por meios especiais, tais como abstinência, concentração e transe, mas mais freqüentemente através do uso de drogas alucinógenas.

A etnografia wari', lida à luz do perspectivismo, sugere a possibilidade de uma interpretação diferente para esse tipo de contradição, que parece muitas vezes relacionada a um desejo explícito de 
mostrar ao etnógrafo a repulsa a crenças que, eles sabem, vemos como irracionais. No caso dos Wari', ao menos, arrisco-me a afirmar que para eles ora os espíritos existem, ora não existem. Não porque não possam vê-los em alguns momentos (só os xamãs podem vê-los), mas porque esses espíritos não fazem parte de seu mundo enquanto Brancos, mas somente de seu mundo wari'. Do mesmo modo que 0 xamã, quando atuando como uma pessoa comum (em seu corpo wari', poderíamos dizer), vê, de um modo geral, os animais como animais, 0 Wari', quando em seu corpo de Branco, pode perfeitamente negar a existência de espíritos animais, visto que esses não fazem parte do mundo visto pela perspectiva dos Brancos.

\section{0 corpo e o seu duplo}

Se parece simples entender por que os Wari' dizem que estão virando Brancos, é estranho que eles não queiram "completar" o processo, mesmo concebendo a possibilidade de reversão, que aconteceria se eles se afastassem dos Brancos e voltassem para 0 mato e para as suas comidas. Digo que não querem completá-lo porque os Wari' insistem em não se casar com Brancos - apesar de se casarem com índios de outras etnias -, e é desse modo, sabemos, que se finaliza um processo de "mudança de identidade". ${ }^{10}$ No caso dos índios de outras etnias, entretanto, o que acabou acontecendo foi a sua incorporação à sociedade wari'. No que diz respeito aos Brancos, os Wari' também não estão interessados em incorporá-los plenamente, porque se recusam a doar suas mulheres para eles. São raras as mulheres wari' casadas com Brancos, e seus parentes são criticados abertamente por terem permitido tais casamentos.

Seria de se esperar justamente o contrário, que os Wari' quisessem doar as suas mulheres para os Brancos, justamente para tê-los como cunhados e genros verdadeiros, para incorporá-los como Wari'. Entretanto, preferem mantê-los como inimigos, como revelam ao continuarem chamando-os assim. Ao mesmo tempo, não abrem mão da conterraneidade com eles: os Wari' não querem voltar para "0 mato" e explicitam que estar junto dos Brancos é uma opção deles.
Esclareço mais uma vez que não estou sugerindo que questões de ordem material não sejam fundamentais nessa opção; é claro que desejam estar perto dos bens dos Brancos, dos machados, dos remédios para as doenças que agora sabem fazer parte das suas vidas, e também dos gravadores, teclados eletrônicos, e dos jogos de futebol e "filmes de porrada" da televisão, hoje presente (uma) em cada aldeia. Se gostam tanto disso, por que então não se casam com os Brancos e se misturam com eles de vez? Por que insistem em evitar 0 único meio realmente eficaz, além da predação (hoje só simbólica), de se consumar uma transformação?

Eu diria que os Wari' querem continuar a ser Wari' sendo Brancos. Em primeiro lugar porque desejam as duas coisas ao mesmo tempo, os dois pontos de vista. Os outros inimigos, aqueles que trouxeram para junto de si, como os OroWin, tornaram-se logo Wari'. É isso o que acontece com a proximidade completada pelo casamento: a identidade. Os Wari', pelo que entendo, não querem ser iguais aos Brancos, mas mantê-los como inimigos, preservar a diferença sem no entanto deixar de experimentá-la. Nesse sentido, vivem hoje uma experiência análoga à de seus xamãs: têm dois corpos simultâneos, que muitas vezes se confundem. São Wari' e Brancos, às vezes os dois ao mesmo tempo, como nos surtos dos xamãs. Se antes aos Wari' cabia a experiência indireta de uma outra posição, a posição do inimigo, hoje experimentam-na em seus corpos.

\section{NOTAS}

1 Gow revela, entretanto, uma surpreendente complexidade desse circuito de apropriações ao mostrar que 0 xamanismo da ayahuasca da Amazônia ocidental, embora considerado pelos etnólogos como "autêntico", teve origem provavelmente entre grupos indígenas que viviam em missões católicas do século XVII.

2 Devo deixar claro que, no que diz respeito à noção de autenticidade, Turner não se refere especificamente às roupas e adereços, mas às casas no estilo regional, que seriam "irreais" ("unregl"), e à "dupla" aldeia de Gorotire, com casas em círculo, ao modo tradicional, e casas em linha, formando uma rua. De acordo com Turner (1991, p. 298), a parte constituída pelo círculo de casas é chamada de "autêntica". 
3 Não há, no vocabulário wari', um nome específico para designar roupa, provavelmente porque antes do contato eles andavam completamente nus. Hoje usam a palavra awam ("algodão", que eles cultivavam e usavam para a decoração corporal) para designar as vestimentas ocidentais.

4 Perrin (1995, p. 39) comenta sobre a difusão, nas Américas e na Ásia setentrional, do tema da relação do xamã com os espíritos animais como uma relação de aliança.

5 Os Wari' dividem-se em seis subgrupos, unidades com forte conotação territorial e que mantêm entre si relações de aliança.

6 Ver Baldus (1937) e Wagley e Galvão (1961 [1949]) sobre os Tenetehara; Silva (1949) sobre os Terena; Oberg (1949) sobre os Terena e Caduveo, e Galvão (1954 e 1957) sobre a área do rio Negro.

7 Cito em particular aqueles realizados por Cardoso de Oliveira (1963, 1964 e 1967), Melatti (1967), Laraia e Da Matta (1967) e, mais recentemente, por Oliveira Filho (1988).

8 Para uma excelente crítica a esses estudos, remeto a Viveiros de Castro (1999).

9 Embora Carneiro da Cunha esforce-se, neste artigo, por desvincular a posição de mediador do xamã da sua constituição corporal múltipla ou "mestiça". Remeto especificamente à parte em que marca a sua diferença em relação a Gow (1996), referente à atribuição do saber xamânico aos chamados mestiços. De acordo com ela: "Não é tanto a mestiçagem [...] que justifica 0 prestígio xamânico, mas a posição relativa na rede fluvial - metáfora de uma posição relativa quanto ao grau generalizador do ponto de vista particular." (Carneiro da Cunha, 1998, p. 11).

10 Contra 0 argumento de que são provavelmente os Brancos que não querem se casar com eles, digo que os Wari' afirmam que são eles que não querem se casar com os Brancos.

\section{BIBLIOGRAFIA}

ARHEM, Kaj. (1993), "Ecosofia makuna”, in F. Correa (org.), La sedva humanizada: edoǵa altema tiva en e trópico húmedo colambiano Bogotá, Instituto Colombiano de Antropología/ Fondo FEN Colombia/ Fondo Editorial CEREC, pp. 109-26.

BAER, Gerhard. (1994), Cosmogóa y shamanismo de los Matsiguenga Quito, Ediciones Abya-Yala.

BALANDIER, Georges. (1951), "La situation coloniale: approche théorique". Cahiess Intemationaux de Soidoge XI: 44-79.

(1971), Sodiogie actudle de l'Afrique Nöre Paris, Presses Universitaires de France.
BALD US, Herbert. (1937), Ensaios de endoga braslèra São Paulo, Companhia Editora Nacional.

BRUNELLI, Gilio. (1996), “D o xamanismo aos xamãs: estratégias Tupi-Mondé frente à sociedade envolvente", in J. Langdon (ed.), Xamanismo no Brasil: novas pespeetivas Florianópolis, UFSC.

CARD O SO DE O LIVEIRA, Roberto. (1963), "Aculturação e fricção interétnica". Améica Latina 6(3): $33-45$.

. (1964), O índio e o mundo dos brancos Brasília, Editora da Universidade de Brasília.

. (1967), "Problemas e hipóteses relativos à fricção interétnica: sugestões para uma metodologia". Reista do Instituto de Ciênias So dais, 4(1): 41-91.

CARNEIRO DA CUNHA, Manuela. (1998), "Pontos de vista sobre a floresta amazônica". Mana. Estur dos de Antropdoga Social, 4(1): 7-22.

CEDI - Centro Ecumênico de Documentação e Informação. (1984), "Povos indígenas no Brasil/ 84". Acanteea Espeial, São Paulo, CED I, 15.

CHAUMEIL, Jean-Pierre. (1983), V ar, savair, panair. Le damamisme de les Yagua du NordEst péuien Paris, Éditions de l'École des Hautes Etudes en Sciences Sociales.

CONKLIN, Beth Ann. (1997), "Body paint, feathers and VCRs: aesthetics and authenticity in Amazonian activism". Ammican Ethndogist, 24(4): 711-37.

CRO CKER, Jon Christopher. (1985), Vital sauls. Boro ro cosmlogy, natural symbolism and shamenism Tucson, Arizona, The University of Arizona Press.

D A MATTA, Roberto. (1976), Um mumb dividida A estrutura sodal dos índios Apinayé Petrópolis, Vozes.

GALVÃO, Eduardo. (1954), "Mudança cultural na região do rio Negro". Anais do XXXI Congesso Intemadional dos Americanistas 1: 313-9.

. (1957), "Estudos sobre a aculturação dos grupos indígenas do Brasil". Reista de Antro pologia, 5(1): 67-74.

. (1979), Encontro de sociedades Rio de Janeiro, Paz e Terra.

GOW, Peter. (1991), Of mixed blook kinship and histary in Peuvian Amazonia Oxford, Clarendon. 
(1996), "River people: shamanism and history in Western Amazonia", in Nicholas Thomas e Caroline Humphrey (eds.), Shame nism histary and the state Ann Harbor, The University of Michigan Press.

HUGH-JONES, Stephen. (1996), "Shamans, prophets, priests and pastors", in Nicholas Thomas e Caroline Humphrey (eds.), Shamanism his tary and the state, Ann Arbor, Michigan University Press.

JACK SON, Jean. (1995), "Culture genuine and spurious: the politics of indianess in the Vaupés". American Ethnologist, 22: 3-27.

LARAIA, Roque e DA MATTA, Roberto. (1967), Índios e castanhiros a empresa extrativa e os índios do médio Tocantins São Paulo, D ifusora Européia do Livro.

LÉVI-STRAUSS, Claude. (1952), Race \& histare Paris, Unesco.

. (1964), Le au \& le ait. Paris, Plon.

. (1967), Du mid aux condres Paris, Plon.

. (1968), L'arigine des manières de table Paris, Plon.

. (1971), L'hommenu Paris, Plon.

. (1991), Histoire de Lynx. Paris, Plon.

MELATTI, Júlio César. (1967), Índios e ciadores a situação dos Krahó na área pastail do Tocantins Rio de Janeiro, Instituto de Filosofia e Ciências Sociais da Universidade Federal do Rio de Janeiro.

OBERG, Kalervo. (1949), "The Terena and the Caduveo of Southern Mato Grosso". Publication of the Institute of Social Anthropology of the Smithsonian Institution, Washington, 9.

OLIVEIRA FILHO, João Pacheco. (1988), “O nosso govemo". Os Tiama e o regime tutdar. São Paulo, Marco Zero/ MCT/ CNPq.

OVERING KAPLAN, Joanna. (1977), "Orientation for paper topics" e "Comments", simpósio "Social Time and Social Space in Lowland South American Societies", Ades du XLII Congès International des Amóricanistes 2: 9-10 e 387-94.

PERRIN, Michel. (1995), Le damanisme Paris, Presses Universitaires de France.

REICHE L-D OLMATOFF, G. (1975), The shaman and the jaguar. Philadelphia, Temple University Press.
RIBEIRO, D arcy. (1957), "Culturas e línguas indígenas do Brasil". Educacãão e Ciênaias Sociais Rio de Janeiro, 2(6): 1-102. . (1996 [1970]), Os índios e a divilizaçãa A integracão das pqulacões indícgnas no Brasil modama São Paulo, Companhia das Letras.

SAHLINS, Marshall. (1981), Historical maaphors and mythical realities Structure in the early histary of the Sandwich Isands kingdom Ann Arbor, The University of Michigan Press.

. (1985), Islands of histary. Chicago/ Londres, The University of Chicago Press.

. (1995), How "natives" think. Abait captain Cook for example Chicago/Londres, The University of Chicago Press.

SEEGER, Anthony. (1980), Os índios e nós Estudbs sobre sociedades tribais brasileras Rio de Janeiro, Campus.

SEEG ER, Anthony, D A MATTA, Roberto eVIVEIRO S DE CASTRO, Eduardo. (1979), "A construção da pessoa nas sociedades indígenas brasileiras". Bdetim do Musau Nadinal, 32: 2-19.

SILVA, Fernando Altenfelder. (1949), "Mudança cultural terena". Revista do Musau Paulista 2: 271379.

TAUSSIG, Michael. (1993), Xamanism, colonialismo e o hamem sedvagem um estudo sobre o terror e a ara. Rio de Janeiro, Paz e Terra.

TERENA, Marcos. (1981), "A Sociedade Branca é uma capa que o índio usa para sobreviver". Fdha de S. Paulo 3/ 5/ 1981, Folhetim.

TO OKER, D eborah. (1992), "Identity systems in Highland Burma: 'belief', Akha Zan and a critique of interiorized notions of ethno-religious identity". Man (N.S.), 27: 799-819.

TURNER, Terence. (1971), "Cosmetics: the language of body adornment", in James P. Spradley e David W. McCurdy (eds.), Conformity and conflict. Readings in Cultural Anthropology, Boston, Little Brown and Company.

(1991), "Representing, resisting, rethinking: historical transformations of Kayapo culture and anthropological consciousness", in G. Stocking Jr. (ed.), Colonial situations Essays on the contextualization of thnographic knowiedge (Handbook of Sath American Indians vol. 7), Madison, The University of Wisconsin Press, pp. 285-313. 
VILAÇA, Aparecida. (1992), Comendo com gente formas do canibalismo nari' (Pakaa Nowa). Rio de Janeiro, Anpocs/ Editora da UFRJ.

. (1996a), "Cristãos sem fé: alguns aspectos da conversão dos Wari' (Pakaa Nova)". Mana Estudos de Antropologia Social, 2(1): 109-37.

. (1996b), Quem somos nós. Questões da àteridade no encontro dos Wari com os Brancos Tese de doutoramento, PPGAS, Museu Nacional, Universidade Federal do Rio de Janeiro.

. (1997), "Christians without faith: some aspects of the conversion of the Wari'". Ethnos, 62: 1-2 e 91-115.

. (1998), "Canibalismo e morte entre os Wari' à luz do perspectivismo". Revista de Antropdoga, 41(1): 9-67.

VIVEIROSD E CASTRO, Eduardo.(1992), “O mármore e a murta: sobre a inconstância da alma selvagem". Revista de Antropologia, 35: 21-74.

. (1995), "Le meurtrier et son double chez les Araweté: un exemple de fusion rituelle". Systèmes de Pensée en Afrique Nair, 14 (D estins de meurtriers): 77-104.

. (1996), "Os pronomes cosmológicos e 0 perspectivismo ameríndio". Mana Estudos de Antropdoga Social, 2(2): 115-43.

. (1999), "Etnologia brasileira", in Sergio Miceli (org.), O que ler na dênia soial brasilèra (1970-1995). Antropologa (vol. I), São Paulo, Editora Sumaré/ Anpocs/ CAPES.

WAG LEY, Charles e G ALVÃO , Eduardo. (1961 [1949]), Os índios Tentehara: uma altura em transção. Rio de Janeiro, Serviço de Comunicação do Ministério da Educação e Cultura.

WEINER, James F. (1997), "Televisualist Anthropology. Representation, aesthetics, politics". Current Anthropdogy, 38(2): 197-235.

WRIG HT, Robin. (1996), "Os guardiões do cosmos: pajés e profetas entre os Baniwa", in J. Langdon (ed.), Xamanismo mo Brasil: movas perspetivas Florianópolis, Editora da UFSC. 